\title{
Influence of Weather Parameters on Colonies Performance Parameters of Indian Bee, Apis cerena indica
}

\author{
Manoj Kumar Painkra*, S.S. Shaw, R.K. Thakur and Yogesh Nag \\ Department of Entomology, I.G.KV. Raipur, India \\ *Corresponding author
}

\begin{tabular}{|c|c|}
\hline & A B S T R A C T \\
\hline & \multirow{6}{*}{$\begin{array}{l}\text { The influence of the various abiotic parameters (temperature, relative humidity, sun shine } \\
\text { hours, and rainfall) on brood area, pollen area, nectar area, strength and honey production } \\
\text { of Indian honey bee, Apis cerana indica were worked out in terms of extent of correlation } \\
\text { starting from the month of September, } 2015 \text { to March, } 2016 \text { at different migratory site of } \\
\text { northern part of India. For the purpose, } 21 \text { days in performance parameter i.e., brood area, } \\
\text { pollen area, bee strength were recorded and correlated with prevailing weather parameters } \\
\text { recorded at meterological unit for the period of a year. The pooled weather data of } \\
\text { September, October, and November of Solan district were used among the weather } \\
\text { parameters relative humidity had a significant but negative correlation with brood area(r }=- \\
0.838 \text { ) and significant and positive correlation with pollen area, the r value being } 0.987 \text {, } \\
\text { the maximum temperature had a significant and positive correlation with pollen area, the } \\
\text { "r" value being } 0.927 \text {, the rainfall exhibited significant and positive correlation with nectar } \\
\text { area, the "r" value being } 0.846 \text { respectively. The weather data of December, January and } \\
\text { February of Hisar district were used among the weather parameters and the maximum } \\
\text { temperature had significant and positive correlation with brood area and bee strength. The } \\
\text { minimum temperature had a significant and positive correlation with pollen area and bee } \\
\text { strength. The study enclosed that all the weather parameters have a great influence on } \\
\text { performance parameters which decide success or failure of honey production or } \\
\text { beekeeping. }\end{array}$} \\
\hline & \\
\hline $\begin{array}{l}\mathrm{Be} \\
\mathrm{Co} \\
\text { pro } \\
\mathrm{Te}\end{array}$ & \\
\hline Article Info & \\
\hline & \\
\hline & \\
\hline
\end{tabular}

\section{Introduction}

Indian bee, Apis cerana is an indigenous bee species found in nature. The various biotic and abiotic factors known to be influence the development of honeybees. Among abiotic factors the various weather parameters like temperature, relative humidity, amount of rain fall, number of rainy days; sunshine hours may have positive or negative influence on developmental parameters of honeybees. The important developmental parameters include brood rearing activity, which measured in terms of area under egg, grub and pupa as well as honey store and pollen store. All the activities are further depending on foraging efficiency of foragers. Greater the foraging activity better the development. Brood rearing is one of the vital activities of honeybee which determine the strength of the colony. The ideal weather for good brood rearing activity in the plains type bees was a mean maximum day temperature of $34.40 \mathrm{C}$, long daily hours of sunshine and completely calm weather (Subbiah, 1956). Reddy (1979) reported that relative humidity and rainfall 
showed a positive relationship with the pollen gathering activity by the bees. Brood rearing can occur at temperature ranging from 37 to 420 C (Naim, 1983). Verma (1983) noticed increase in the pollen foraging activity with rise in the relative humidity, but not so affected by temperature. Mahrotra and Bisht (1984) found significant correlation of foraging activity for pollen and nectar foragers with day temperature and humidity. Abrol and Bhat (1987) reported that the foraging activity of $A$. cerana was significant and positive with temperature and nonsignificant with relative humidity.

Kaur and Sihag (1994) observed that the numbers of pollen foragers were positively and highly significantly correlated with the temperature and negatively and highly significantly with the relative humidity. Brood population of Apis cerana indica worker exhibited a significant, negative and linear correlation with minimum and maximum temperature, relative humidity and rainfall, however, positive correlation was observed with bright sunshine hours (Das and Rahman, 2000).

To avail the information on influence of different weather factors on brood rearing activity, honey and pollen store as well as foraging efficiency of worker bees the present studies has been undertaken.

\section{Materials and Methods}

To study the influence of various weather parameters and to record observations on brood area, honey production, pollen area, bee strength and nector area as well as foraging activity of pollen forager, five colonies of $A$. cerana of uniform strength reared in standard ISI- 8 type bee hives maintained at three migratory site dist. Solan, Hisar and Ambala of northern part of India for the period of September 2015 to march 2016. The colonies were examined regularly at 21 days interval and observations on colony growth parameters like total brood area, pollen area, bee strength and honey stores were recorded utilizing standard technique. For the purpose, determine the brood population by using measurement scale. The scale used to measure the brood area, length and width of brood area and total unit brood area observation were taken and analyzed in $\mathrm{cm}^{2}$. The total brood unit areas were calculated from the area occupied by the brood. In addition to this, the comb areas occupied by pollen and nectar stores were also measured in the same way. Each observation was made for five minutes. The observations were recorded throughout the study period. The parameters like pollen area, honey production, nectar area and total brood area were correlated with the various weather parameters like maximum and minimum temperature, relative humidity, sunshine hours, rainfall. The data on the various weather parameters recorded by the Meteorological Department, College Farm, Solan University were utilized. The extent of correlation was worked out by using Karl Pearson's co-efficient test.

\section{Results and Discussion}

The results on the investigation on the influence of various weather parameters on brood area, honey production, bee strength, nectar area and pollen area of Indian honey bee, A. cerana were made in terms of extent of correlation for the September 2015 to March 2016 and pooled are presented in Table 1.

The influence of weather parameters on various developmental activity of honey bee colony was worked out by calculating the extent of correlation between them. For the purpose coefficient of correlation (r) was worked out and compared with table value at $5 \%$ and $1 \%$ level of significance. 
Effect of weather parameters on colonies performance parameters of Apis cerana indica at Saryanj, Solan (H.P)

The pooled weather data of September, October, and November of Saryanj village of Solan district were used among the weather parameter and are presented in Table 2. The relative humidity had a significant but negative correlation with brood area, the " $\mathrm{r}$ " value being -0.838 , Similarly the relative humidity had a significant but negative correlation with bee strength, Further, the relative humidity had a significant and positive correlation with pollen area, the " $r$ " value being 0.987 . The maximum temperature had significant but negative correlation with bee strength at $5 \%$ level, the " $\mathrm{r}$ " value being 0.783 , the maximum temperature had a significant and positive correlation with pollen area, the "r" value being 0.927 The minimum temperature had a significant and positive correlation with pollen area at 5\% level, the " $r$ " value being 0.715 . Among the other weather parameters, the sunshine hours had a significant and positive correlation with nectar area at $5 \%$ level, the " $r$ " value being 0.735 , The rainfall had a significant and positive correlation with nectar area, the " $r$ " value being 0.922 , Similarly the rainfall had a significantly and positive correlation with honey production, the " $r$ " value being 0.846 . The present result are in close agreement with earlier report on influence of weather parameter on brood rearing and foraging activity by Apis cerana reported by Pastagia et al., (2014).

\section{Effect of weather parameters on colonies performance parameters of Apis cerana indica at Umra, Hisar (Haryana)}

The pooled weather data of December, January and February of Umra village of Hisar district were used among the weather parameters and the maximum temperature had significant and positive correlation with brood area, the "r" value being 0.996 , similarly the maximum temperature had a significant and positive correlation with bee strength, the " $\mathrm{r}$ " value being 0.963 . The maximum temperature had a significant but negative correlation with honey production, the " $r$ " value being -0.956 , The minimum temperature had a significant and positive correlation with pollen area at 5 $\%$ level, the "r" value being 0.802 , Similarly the minimum temperature had significant and positive correlation with bee strength $5 \%$ level, the " $r$ " value being 0.829 . The relative humidity had significant but negative correlation with brood area, the " $r$ " value being -0.975 , similarly the relative humidity had significant but negative correlation with bee strength, the " $r$ " value being -0.927 . Thus the study indicated that more humidity had adverse affect on the brood development of Indian honey bee.

\section{Effect of weather parameters on colonies performance parameters of Apis cerana indica at Naraingarh, Ambala (Haryana)}

The weather data of March of Naraingarh village Ambala district were used and are presented in Table 2. Among the weather parameters the minimum temperature had a significant and positive correlation with brood area, the " $r$ " value being 0.755 , The minimum temperature had a significant and positive correlation with bee strength, the " $\mathrm{r}$ " value being 0.967 , Similarly the minimum temperature had a significant and positive correlation with pollen area, the "r" value being 0.972 and The minimum temperature had a significant and negative correlation with honey production, the " $\mathrm{r}$ " value being 0.875 . The relative humidity had significant and positive correlation with brood area, the " $r$ " value being 0.820 similarly the relative humidity had significant and positive correlation with bee strength, the "r" value being 0.846 , and the relative humidity had significant and positive correlation with pollen area, the " $r$ " value being 0.878 . 
Table.1 Effect of weather parameter on colony performance parameter of Apis cerana indica at different migratory site

\begin{tabular}{|c|c|c|c|c|c|c|c|c|c|c|c|c|c|c|c|}
\hline & \multicolumn{3}{|c|}{ Brood area $\left(\mathrm{cm}^{2}\right)$} & \multicolumn{3}{|c|}{ Strength } & \multicolumn{3}{|c|}{ Pollen area $\left(\mathrm{cm}^{2}\right)$} & \multicolumn{3}{|c|}{ Nectar area $\left(\mathrm{cm}^{2}\right)$} & \multicolumn{3}{|c|}{ Honey production (kg.) } \\
\hline & Saryanj & Umra & Naraingarh & Saryanj & Umra & Naraingarh & Saryanj & Umra & Naraingarh & Saryanj & Umra & Naraingarh & Saryanj & Umra & Naraingarh \\
\hline $\begin{array}{l}\text { Maximum } \\
\text { temp. }\end{array}$ & -0.685 & $0.996 * *$ & 0.024 & $-0.783 *$ & $0.963 * *$ & 0.629 & $0.927 * *$ & 0.636 & 0.495 & -0.340 & -0.461 & 0.053 & -0.489 & -0.539 & -0.451 \\
\hline $\begin{array}{l}\text { Minimum } \\
\text { temp. }\end{array}$ & -0.351 & 0.697 & $0.755^{*}$ & -0.488 & $0.829 *$ & $0.967 * *$ & $0.715^{*}$ & $0.802 *$ & $0.972^{* *}$ & 0.043 & -0.337 & 0.272 & -0.120 & $-\overline{-}^{-} 956^{* * *}$ & $-0.875^{* *}$ \\
\hline $\begin{array}{l}\text { Relative } \\
\text { humidity }\end{array}$ & $\overline{0}-838^{* *}$ & $-\overline{0.975^{* *}}$ & $0.820 *$ & $-\overline{0.908 * *}$ & $-\overline{0.927 * *}$ & $0.846^{* *}$ & $0.987 * *$ & -0.392 & $0.878^{* *}$ & -0.553 & 0.648 & $0.718^{*}$ & -0.682 & 0.440 & $-0.943 * *$ \\
\hline $\begin{array}{l}\text { Sun shine } \\
\text { hours }\end{array}$ & 0.405 & 0.449 & $-0.804 *$ & 0.269 & 0.249 & $-0.987 * *$ & 0.014 & 0.396 & $-0.996^{* *}$ & $0.735^{*}$ & 0.343 & -0.410 & 0.614 & 0.351 & $0.940 * *$ \\
\hline Rain fall & 0.692 & & 0.195 & 0.580 & & 0.679 & -0.326 & & 0.549 & $0.922 * *$ & & $0.942 * *$ & $0.846^{* *}$ & & $-0.795^{*}$ \\
\hline
\end{tabular}

** Significantat $1 \%$ levelof significance $(\mathrm{p}<0.01)(\mathrm{r}=0.834)$

Table.2 Correlation and regression equation between performance parameters and weather parameters at Saryanj village, Solan (H.P.)

\begin{tabular}{|c|c|c|c|c|c|}
\hline \multirow[b]{2}{*}{ SN. } & \multirow{2}{*}{$\begin{array}{l}\text { Correlation between performance } \\
\text { Parameters and weather parameters }\end{array}$} & \multirow{2}{*}{ "r" value } & \multirow{2}{*}{ Regression equation } & \multicolumn{2}{|c|}{ Significance of level } \\
\hline & & & & $5 \%$ & $1 \%$ \\
\hline 1 & Relative humidity v/s brood area & $-0.838 * *$ & $\mathrm{Y}_{3}=6.017-266.4 \mathrm{X}_{5}$ & Yes & Yes \\
\hline 2 & Relative humidity v/s bee strength & $-0.908 * *$ & $Y=-1.679+119.4 X_{5}$ & Yes & Yes \\
\hline 3 & Relative humidity v/s pollen area & $0.987 * *$ & $\mathrm{Y}_{4}=8.868-602.0 \mathrm{X}_{5}$ & Yes & Yes \\
\hline 4 & Maximum temperature $\mathrm{v} / \mathrm{s}$ bee strength & $0.783 *$ & $Y=-0.587+19.07 X_{6}$ & Yes & - \\
\hline 5 & Maximum temperature $\mathrm{v} / \mathrm{s}$ pollen area & $0.927 * *$ & $Y_{4}=3.369-79.59 \mathrm{X}_{6}$ & Yes & Yes \\
\hline 6 & Minimum temperature v/s pollen area & $0.715^{*}$ & $Y_{4}=1.125-1.463 X_{7}$ & Yes & - \\
\hline 7 & Sunshine v/s nectar area & $0.735^{*}$ & $\mathrm{Y}_{1}=-42.80+361.1 \mathrm{X}_{8}$ & Yes & \\
\hline 8 & Rainfall v/s nectar area & $0.922 * *$ & $\mathrm{Y}_{1}=58.91+76.81 \mathrm{X}_{9}$ & Yes & Yes \\
\hline 9 & Rainfall v/s honey production & $0.846^{* *}$ & $\mathrm{Y}_{2}=0.346+0.409 \mathrm{X}_{9}$ & Yes & Yes \\
\hline
\end{tabular}

Note: $*$ Significant at 5\% level of significance $(\mathrm{p}<0.05)(\mathrm{r}=0.704)$

** Significant at $1 \%$ level of significance $(\mathrm{p}<0.01)(\mathrm{r}=0.834)$ 
Table.3 Correlation and regression between performance parameters and weather parameters at Umra village, Hisar (Haryana)

\begin{tabular}{clcccc}
\hline \hline SN & \multirow{2}{*}{$\begin{array}{c}\text { Correlation between performance } \\
\text { Parameters and weather parameters }\end{array}$} & "r" value & Regression equation & \multicolumn{2}{c}{$\begin{array}{c}\text { Significance of } \\
\text { level }\end{array}$} \\
\cline { 4 - 6 } & & & & $5 \%$ & $1 \%$ \\
\hline 1 & Maximum temperature v/s brood area & $0.996^{* *}$ & $\mathrm{Y}_{3}=45.26-659.7 \mathrm{X}_{6}$ & Yes & Yes \\
2 & Maximum temperature v/s bee strength & $0.963^{* *}$ & $\mathrm{Y}=0.202+1.098 \mathrm{X}_{6}$ & Yes & Yes \\
3 & Maximum temperature v/s honey production & $-0.956^{* *}$ & $\mathrm{Y}_{2}=-0.136+5.369 \mathrm{X}_{6}$ & Yes & Yes \\
4 & Minimum temperature v/s pollen area & $0.802^{*}$ & $\mathrm{Y}_{4}=7.422+73.65 \mathrm{X}_{6}$ & Yes & - \\
5 & Minimum temperature v/s bee strength & $0.829^{*}$ & $\mathrm{Y}^{2}=0.169+4.174 \mathrm{X}_{7}$ & Yes & - \\
6 & Relative humidity v/s brood area & $-0.975^{* *}$ & $\mathrm{Y}_{3}=-19.84+1754 \mathrm{X}_{5}$ & Yes & Yes \\
7 & Relative humidity v/s bee strength & $-0.927^{* *}$ & $\mathrm{Y}=0.087+11.79 \mathrm{X}_{5}$ & Yes & Yes \\
\hline
\end{tabular}

Note * Significant at $5 \%$ level of significance $(\mathrm{p}<0.05)(\mathrm{r}=0.704)$

** Significant at $1 \%$ level of significance $(\mathrm{p}<0.01)(\mathrm{r}=0.834)$

Table.4 Correlation and regression between performance parameters and weather parameters at Naraingarh village, Ambala

\begin{tabular}{|c|c|c|c|c|c|}
\hline \multirow[b]{2}{*}{ SN. } & \multirow{2}{*}{$\begin{array}{l}\text { Correlation between performance } \\
\text { Parameters and weather parameters }\end{array}$} & \multirow{2}{*}{ "r" value } & \multirow{2}{*}{ Regression equation } & \multicolumn{2}{|c|}{ Significance of level } \\
\hline & & & & $5 \%$ & $1 \%$ \\
\hline 1 & Minimum temperature $\mathrm{v} / \mathrm{s}$ brood area & $0.755^{*}$ & $\mathrm{Y}_{3}=7.497+182.9 \mathrm{X}_{7}$ & Yes & - \\
\hline 2 & Minimum temperature $\mathrm{v} / \mathrm{s}$ bee strength & $0.967 * *$ & $Y=0.165+4.677 X_{7}$ & Yes & Yes \\
\hline 3 & Minimum temperature v/s pollen area & $0.972 * *$ & $\mathrm{Y}_{4}=13.34+57.27 \mathrm{X}_{7}$ & Yes & Yes \\
\hline 4 & Minimum temperature v/s honey production & $-0.875 * *$ & $Y_{2}=-0.156+4.533 \mathrm{X}_{7}$ & Yes & Yes \\
\hline 5 & Relative humidity v/s brood area & $0.820^{*}$ & $\mathrm{Y}_{3}=5.458-102.5 \mathrm{X}_{5}$ & Yes & - \\
\hline 6 & Relative humidity v/s bee strength & $0.846 * *$ & $Y=0.097-0.011 X_{5}$ & Yes & Yes \\
\hline 7 & Relative humidity v/s pollen area & $0.878^{* *}$ & $\mathrm{Y}_{4}=8.113-339.3 \mathrm{X}_{5}$ & Yes & Yes \\
\hline 8 & Relative humidity $\mathrm{v} / \mathrm{s}$ nectar area & $0.718^{*}$ & $Y_{1}=40.61-1741 X_{5}$ & Yes & - \\
\hline 9 & Relative humidity v/s honey production & $-0.943 * *$ & $Y_{2}=-0.113+10.45 X_{5}$ & Yes & Yes \\
\hline 10 & Sunshine hour v/s brood area & $-0.804 *$ & $Y_{3}=-29.35+509.6 X_{8}$ & Yes & - \\
\hline 11 & Sunshine hour $\mathrm{v} / \mathrm{s}$ bee strength & $-0.987 * *$ & $Y=-0.622+11.68 X_{8}$ & Yes & Yes \\
\hline 12 & Sunshine hour v/s pollen area & $0.996 * *$ & $Y_{4}=-50.47+624.7 X_{8}$ & Yes & Yes \\
\hline 13 & Sunshine hour v/s honey production & $0.940 * *$ & $Y_{2}=0.619-2.331 X_{8}$ & Yes & Yes \\
\hline 14 & Rainfall v/s nectar area & $0.942 * *$ & $Y_{1}=264.4+846.3 X_{9}$ & Yes & Yes \\
\hline 15 & Rainfall v/s honey production & $0.795^{*}$ & $Y_{2}=-0.470+2.998 X_{9}$ & Yes & - \\
\hline 13 & Sunshine hour v/s honey production & $0.940 * *$ & $\mathrm{Y}_{2}=0.619-2.331 \mathrm{X}_{8}$ & Yes & Yes \\
\hline 14 & Rainfall v/s nectar area & $0.942 * *$ & $Y_{1}=264.4+846.3 X_{9}$ & Yes & Yes \\
\hline 15 & Rainfall v/s honey production & $0.795^{*}$ & $Y_{2}=-0.470+2.998 X_{9}$ & Yes & - \\
\hline
\end{tabular}


The relative humidity had significant and positive correlation with nectar area, the " $r$ " value being 0.718 , The relative humidity had significant and positive correlation with honey production, the " $r$ " value being -0.943 . Thus, the relative humidity had positive effect on the development of honey bee population except the honey production. The sunshine hours had a significant but negative correlation with brood area, the " $r$ " value being 0.804 , Similarly sunshine hours had a significant but negative correlation with bee strength, the " $r$ " value being -0.987 , the sunshine hours had a significant and positive correlation with pollen area, the " $r$ " value being 0.996 , Similarly sunshine hours had a significant and positive correlation with honey production, the " $r$ " value being 0.940 . Thus, the sunshine hours had same adverse effect on bee development but foragers honey bee for more pollen collection and more honey production by way of collecting more nectar from the foragers due to availability of more working time due to more sunshine hours (Tables 3 and 4).

The rainfall had a significant and positive correlation with nectar area, the " $r$ " value being 0.942 and similarly the rainfall had a significant and positive correlation with honey production, the " $r$ " value being - 0.795. Similarly the rainfall had positive effect for honey bee this might be due to more foragers i.e. bee flora available for honey bee for foraging activity in Naraingarh village of Ambala district of Haryana state. Pastagia et al., (2014) have also reported that influence of weather parameters on brood rearing and foraging activity of Indian bee Apis cerana and their work revealed that the minimum temperature, relative humidity and rainfall exhibited significant and negative correlation with brood area, pollen area and nectar area. While, sunshine hours exhibited significant and positive influence on nectar area and pollen area. Das and Rahman (2000) reported that brood population of Apis cerana indica worker exhibited a significant negative and linear correlation with minimum and maximum temperature, relative humidity and rainfall and a significant positive and linear correlation with bright sunshine hours which are in close agreement with the present investigation.

From the investigation in nutshell, it can be evident that the weather parameters contribute major role in influencing the brood rearing, pollen area, nectar area, bee strength and honey production as well as the activity of pollen foragers of Apis cerana indica at migratory mode in northern part of India.

\section{References}

Abrol, D.P. and Bhat, A.A. (1987). Influence of atmospheric conditions and floral rewards on diurnal activity pattern, flower visitation rates and pollinating effectiveness of Apis ceranaindica foragers. Res. Develop. Reporter, 4(1):13-16.

Das, P.K. and Rahman, A. 2000. Brood reairing activity of Apis cerana indica F. In Assam. Crop. Res. 19(3): 469-473.

Kaur, G. and Sihag, R.C. (1994). Effect of weather factors on the colony foraging of honeybees (Apis mellifera L.). Indian Bee J., 56(3/4): 158-162.

Pastagia, J.J. and Patel, M.B. 2014. Influence of weather parameters on brood rearing and foraging activities of Indian bee, Apis cerena. AGRES - An International Journal. Vol.3: 403-409.

Reddy, C.C. (1979). The influence of various meteorological factors on the foraging behaviour of Apis cerana indica. Proc. 4th Int. Symp. Pooln. College Park, Myrland, U.S.A., pp 341345.

Verma, S. (1983). Studies on foraging behaviour of Apis cerana indica $\mathrm{F}$. in Jeolikote, Nainital, India. Indian Bee J., 45: 5-9.

\section{How to cite this article:}

Manoj Kumar Painkra, S.S. Shaw, R.K. Thakur and Yogesh Nag. 2017. Influence of Weather Parameters on Colonies Performance Parameters of Indian Bee, Apis cerena indica. Int.J.Curr.Microbiol.App.Sci. 6(11): 2375-2380. doi: https://doi.org/10.20546/ijcmas.2017.611.281 